\title{
FAILURE TO ERADICATE HIV DESPITE FULLY SUCCESSFUL HAART INITIATED IN THE FIRST DAYS OF LIFE
}

\author{
Alessandra Viganò, mD, Daria Trabattoni, PhD, laura Schneider, MD, Francesco Ottaviani, MD, Antonia Aliffi, MD, \\ Erika longhi, PhD, Stefano Rusconi, MD, and Mario Clerici, MD
}

Highly active antiretroviral therapy (HAART) started shortly after birth resulted in reversion of human immunodeficiency virus (HIV) plasma viremia, proviral DNA in PBMC, viral culture, and serum HIV antibodies to negative. Discontinuation of HAART 2 years after apparent HIV eradication, however, was followed by virus replication, CD4 decline, and destruction of HIV-specific lymphocytes, epitomizing the impossibility of HIV eradication. (J Pediatr 2006;148:389-91)

I $\mathrm{n}$ vertical human immunodeficiency virus (HIV) infection, the first months after birth are characterized by rapid plasma viral turnover and extremely high HIV plasma viremia. ${ }^{1}$ Because HIV viral load is predictive of subsequent disease course, and disease progression is accelerated in HIV-infected children, ${ }^{2}$ early, potent combination therapy regimens could provide the best opportunity to control viral replication and to preserve the immune system. Data in adults showing that initiation of antiviral therapy during acute infection (or even before seroconversion) can result in control of viral replication even after therapy is interrupted ${ }^{3}$ further strengthen this suggestion. We report the case of a child in whom this hypothesis was tested.

\section{CASE REPORT}

The patient was a female, born by cesarean delivery at 38 weeks gestation to a mother who had seroconversion for HIV 2 weeks earlier. HIV testing was performed because the husband was newly diagnosed to be infected with HIV. Maternal CD4 counts and HIV RNA at week 37 were $987 / \mu \mathrm{L}$ and 139,000 copies/mL, respectively. Intrapartum and peripartum prophylaxis was performed with zidovudine $(2 \mathrm{mg} / \mathrm{kg}$ bolus intravenously, followed by $1 \mathrm{mg} / \mathrm{kg} / \mathrm{h}$ until the end of the cesarean procedure) + nevirapine $(200 \mathrm{mg}$ once) in the mother, and zidovudine orally $(2 \mathrm{mg} / \mathrm{kg}$ every 6 hours) in the newborn. Virologic analyses were performed on the newborn within 48 hours of birth: qualitative HIV-RNA was positive, and HIV plasma viremia was 15,300 copies $/ \mathrm{mL}$. Antiviral therapy with zidovudine (150 $\left.\mathrm{mg} / \mathrm{m}^{2} / \mathrm{d}\right)+$ lamivudine $(4 \mathrm{mg} / \mathrm{kg} / \mathrm{d})+$ nevirapine $\left(160 \mathrm{mg} / \mathrm{m}^{2} / \mathrm{d}\right)$ was initiated within 1 week after birth; therapy led to full suppression of HIV plasma viremia $(<50$ copies $/ \mathrm{mL})$ and stabilization of the CD4 counts and of the CD4/CD8 ratio (Table). Serum HIVspecific antibodies and HIV-DNA polymerase chain reaction (PCR) were undetectable 18 months after initiation of therapy; this result was confirmed 3 times during the follow-up period. After 23 months of HAART, HIV proviral DNA-PCR in PBMC was assessed for gag and env regions in 10 replicates (ie, 10 different PCR tests). HIV-1 proviral genome was investigated by a nested PCR. Primers were designed on the HXB2 genome sequence spanning the V3 loop and gag region. HIV viral cultures were performed at the same time, following standard methods. Results were negative. A bilateral tonsillectomy was performed at the same time; histologic study of the tonsils was normal, and tonsillar proviral HIV-1 DNA (GeneAmplimer HIV-1; Applied Biosystems, Foster City, CA) was negative. Functional immunologic analyses were performed as well at this time and showed a strong gag- and env-specific proliferative response, a high percentage of circulating gag- and env-specific interleukin-2 and interferon (IFN) gamma-producing CD4+ T lymphocytes, and a minimal amount of activated T cells (Figure). On the basis of these results, the antiviral therapy was stopped. Within 1 month, the CD4 count dropped from 3674 to $2174 / \mathrm{mL}$, and HIV plasma viremia rose to 46,850 copies $/ \mathrm{mL}$. This

From the Departments of Paediatrics, Immunology, and Otorhinolaryngology; University of Milan, the Department of Infectious Diseases, Cannizzaro Hospital, Catania, and the Infectious Diseases Section, Department of Clinical Sciences, Luigi Sacco Hospital, Milan, Italy.

Supported by grants from the Istituto Superiore di Sanita' 'V Programma Nazionale di Ricerca sull' AIDS 2004"; the Centro di Eccellenza CISI; the EMPRO and AVIP EC WP6 Projects; the "Fondo Incentivazione Ricerca di Base" MIUR, and the Japan Health Science Foundation.

Submitted for publication Jul 4, 2005; last revision received Sep 19, 2005; accepted Nov 14, 2005

Reprint requests: Mario Clerici MD, University of Milano DISP LITA Vialba, Via G.B. Grassi 74, 20157 Milano, Italy. E-mail address: mario.clerici@unimi.it. 0022-3476/\$ - see front matter reserved.

10.1016/j.jpeds.2005.11.037 
Table. Virologic and immunologic test results from birth to discontinuation of antiretroviral therapy at 24 months of age

\begin{tabular}{lcccccc}
\hline & Birth & I Month & 6 Months & I2 Months & I8 Months & 24 Months \\
\hline CD4 count (cell/mm I $^{3}$ ) & NT' & 3531 & 5872 & 3240 & 3176 & 246 I \\
CD4:CD8 ratio & NT & 2.40 & 2.50 & 3.00 & 2.05 \\
HIV RNA (copies/mL) & 15300 & $<50$ & $<50$ & $<50$ & $<8$ & $<50$ \\
Serum HIV-specific Ab & + & N.T. & + & + & - & - \\
\hline
\end{tabular}

'NT $=$ Not tested.
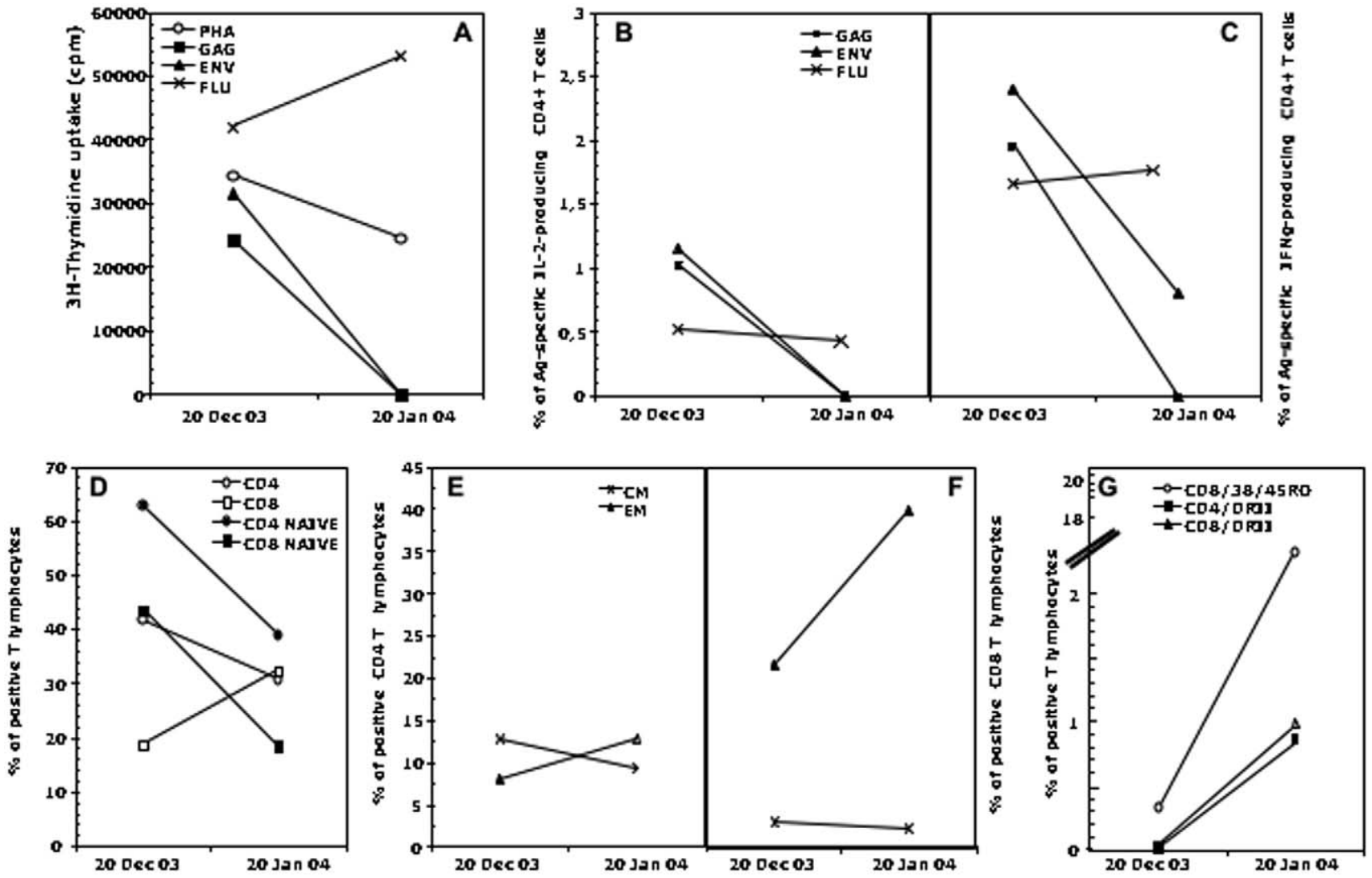

Figure. Immunologic analyses in child examined 2 years after initiation of HAART within days of birth and after reversion of all clinical and virologic test results to negative. A, Proliferative response by peripheral blood mononuclear cells stimulated with HIV antigens (gag and env), influenza A virus $(F L U)$ and phytohemagglutinin $(P H A)$. B, Antigen-stimulated, IL-2-producing CD4+ T lymphocytes. C, Antigen-stimulated, IFN $\gamma$-producing CD4+ T lymphocytes; D, CD4+ and CD8 + T lymphocytes and CD4+ naive (CD45RA/CD621/CCR7+), as well as CD8 naive (45RA/CCR7+) T

lymphocytes. E, CD4+ central memory $(C M)$ and effector memory $(E M)$ T lymphocytes. F, CD8+ central memory $(C M)$, and effector memory $(E M)$ T lymphocytes. G, Activation markers. All analyses were performed at interruption of HAART (20 Dec 2003) and 1 month thereafter (20 Dec 2004$)$. In all cases background was subtracted.

was accompanied by drastic reduction of HIV-specific proliferation (Figure, panel $A$ ), of gag- and env-specific, IL-2 and IFN gamma-producing CD4+ T lymphocytes (Figure, panel $B$ and $C$ ), and of naive $\mathrm{T}$ lymphocytes (panel $D$ ), and by a significant increase of memory cells (Figure, panel $E$ and $F$ ), as well of activated $\mathrm{T}$ cells (panel $G$ ). Influenza A virusspecific (FLU) proliferation and cytokine production was not affected. The patient did not restart therapy; this decision was taken by the family. At the last visit (June 2005) the child was symptom free; HIV RNA was 15,261 copies/mL, and the CD4 count was 1400 , with a CD4 percentage of $24 \%$.

\section{DISCUSSION}

The promptness with which therapy was initiated, the reversion of all virologic tests to negativity, the absence of HIV in accessible lymphatic sites, the disappearance of serum HIVspecific antibodies, and normalcy of clinical features led us to believe that eradication might have been achieved in this child. Soon after interruption of HAART, however, HIV viremia rebounded, CD4 counts declined, HIV-specific and naïve T lymphocytes and central memory $\mathrm{T}$ lymphocytes dropped, and markers of lymphocyte-activation significantly increased. 
The detection of HIV-specific T helper lymphocytes during antiviral therapy, however, may have been a clue that HIV was replicating in some sanctuary, inaccessible even by B lymphocytes. In fact, repeated observations have demonstrated that the magnitude and the breadth of HIV-specific immune response wanes within months after cessation of exposure to the virus in uninfected newborns of HIV-seropositive women. ${ }^{4,5}$ On the other hand, the immunologic results could have further reinforced the possibility of eradication, as in this patient: (1) gag-specific T helper responses were strong, and these responses have repeatedly been associated with immunologic control of HIV infection ${ }^{6}$; and (2) immune activation, an unfavorable prognostic factor, was not detected.

Perinatal exposure to high antigenic loads can lead to tolerance. This phenomenon could explain the lack of immunologic control seen in this child, but it is unlikely given that HIV-specific responses were detected. Lack of cytotoxic T lymphocytes (CTL) maturation and function stemming from exposure to a suboptimal antigen load or from a direct effect of the antiviral therapy also could justify these results. This was not examined. The low HIV-specific CD8 lymphocyte responses frequently detected in vertically-infected young infants ${ }^{7}$ and lack of CTL activity could lead to the infant's inability to contain the replication of HIV hidden in reservoirs. Within 1 month of therapy interruption HIV-specific immune responses disappeared, whereas influenza-specific $T$ lymphocytes were not affected. In spite of 2 years of complete remission of HIV virologic parameter, virus-specific immune responses in less than 30 days after cessation of therapy. The lesson that can be drawn from this case is that the ability of HIV to hide and persist, even in the face of a prompt therapeutic intervention immediately after birth and of the disappearance of virus-specific serum antibodies, is remarkably potent.

\section{REFERENCES}

1. Luzuriaga $\mathrm{K}, \mathrm{Wu} \mathrm{H}, \mathrm{McManus} \mathrm{M}$, Britto $\mathrm{P}$, Borkowsky W, Burchett S, et al. Dynamics of human immunodeficiency virus type 1 replication in vertically infected infants. J Virol 1999;73:362-7.

2. Abrams EJ, Weedon J, Steketee RW, Lambert G, Bamji M, Brown T, et al. Association of human immunodeficiency virus (HIV) load early in life with disease progression among $\mathrm{HIV}$-infected infants. J Infect Dis 1998;178:101-8.

3. Rosenberg ES, Altfeld M, Poon SH, Phillips MN, Wilkes BM, E1dridge RL, et al. Immune control of HIV-1 after early treatment of acute infection. Nature 2000;407:523-6.

4. Clerici M, Sison AV, Berzofsky JA, Rakusan TA, Brandt CD, Ellaurie $\mathrm{M}$, et al. Cellular immune factors associated with mother-to-infant transmission of HIV. AIDS 1993;7:1427-35.

5. Luzuriaga K, McManus, MM, Catalina MD, Mayack S, Sharkey M, Stevenson M, et al. Early therapy of vertical human immunodeficiency virus type 1 (HIV-1) infection: control of viral replication and absence of persistence HIV-1-specific immune responses. J Virol 2000;74:6984-6991.

6. Martinez V, Costagliola D, Bonduelle O, N'go N, Schnuriger A, Theodorou I, et al. Combination of HIV-1-specific CD4 Th1 cell responses and IgG2 antibodies is the best predictor for persistence of long-term nonprogression, J Inf Dis 2005;191:2053-63.

7. Scott ZA, Chadwick EG, Gibson LL, Catalina MD, McManus MM, Yogev r, et al. Infrequent detection of HIV-1-specific, but not of cytomegalovirus-specific CD8+ Tcell responses in young HIV-1-infected infants. J Immunol 2001;167:7134-40. 